\title{
Article \\ Effect of Incense Ash on the Engineering Properties of Cement-Based Composite Material
}

\author{
Wen-Ten Kuo * $\mathbb{B}$, Chuen-Ul Juang and Tzu-Yi Chen \\ Department of Civil Engineering, National Kaohsiung University of Science and Technology, \\ Kaohsiung 807, Taiwan; vivian820830@gmail.com (C.-U.J.); n00475@yahoo.com.tw (T.-Y.C.) \\ * Correspondence: wtkuo@nkust.edu.tw
}

Citation: Kuo, W.-T.; Juang, C.-U.; Chen, T.-Y. Effect of Incense Ash on the Engineering Properties of Cement-Based Composite Material. Appl. Sci. 2021, 11, 4186. https:// doi.org/10.3390/app11094186

Academic Editor: Doo-Yeol Yoo

Received: 10 March 2021

Accepted: 20 April 2021

Published: 4 May 2021

Publisher's Note: MDPI stays neutral with regard to jurisdictional claims in published maps and institutional affiliations.

Copyright: (c) 2021 by the authors. Licensee MDPI, Basel, Switzerland. This article is an open access article distributed under the terms and conditions of the Creative Commons Attribution (CC BY) license (https:/ / creativecommons.org/licenses/by/ $4.0 /)$.

\begin{abstract}
This study investigated the effect of substituting cement with incense ash on material properties and hydration of cement-based composite materials. Test specimens with incense ash replacing up to $30 \%$ (volume) of cement were produced and cured at $25^{\circ} \mathrm{C}$ and $75{ }^{\circ} \mathrm{C}$ for up to 120 days. The researchers of this study observed the effect on setting time, heat conduction, compressive strength, and water absorption, and conducted a microanalysis to observe the structural change of hydration products. The results indicated that by substituting cement with incense ash, the hydration reaction was hastened, and the setting time shortened. When $5 \%$ of cement was replaced, incense ash had the effect of filling the voids between particles. At a higher curing temperature, the frequency of particle collisions increased, expediting the hydration reaction and improving the strength of the specimens. At a longer curing time, voids in the specimens were gradually filled by colloids, and pozzolanic reaction caused the amount of $\mathrm{Ca}(\mathrm{OH})_{2}$ to diminish and C-S-H gel to increase, which in turn improved the structural cohesion, reduced the water absorption, and increased the strength and thermal conductivity of the specimens.
\end{abstract}

Keywords: incense ash; cement-based composite material; engineering properties; compressive strength

\section{Introduction}

In Taiwan, incense is among the most common sacrificial offerings in religious activities, as burning incense signifies acquiring the blessing of spirits. The prevalence of religious activities results in at least 4190 tons of incense being burned annually in temples across Taiwan [1]. Incense is primarily comprised of powdered plant materials [2]. The ash of burned incense is typically treated as waste and deposited in landfills. Therefore, if it can be recycled as an alternative building material, its environmental impact will be substantially reduced. Berraa et al. [3] identified two peaks in the X-ray diffraction (XRD) pattern of wood ash at the $2 \theta$ angles of $27^{\circ}$ and $29^{\circ}$, which corresponded to $\mathrm{SiO}_{2}$ and $\mathrm{CaO}$, respectively. This is consistent with the XRD pattern of incense ash. The chemical composition of the ash of a biomaterial can vary with burning temperature and degree of combustion (complete or incomplete). The volume and mass of ash are largely determined by its biomaterial properties and the production of the plant $[4,5]$. The chemical composition of the ash of a biomaterial is comparable to that of cement; thus, the ash can be added to or replace cement as a bonding material. According to Lin et al. [6], Ca and $\mathrm{K}$ are the metal elements with the highest concentrations in incense ash, followed by $\mathrm{Al}, \mathrm{Mg}, \mathrm{Fe}$, and $\mathrm{Na}$; most of the Ca exists in the form of inorganic salts such as calcium carbonate. Hawley and Wise [7] reported that incense ash typically consists of $40-70 \%$ calcium oxide, $10-30 \%$ potassium oxide, $5-10 \%$ manganese oxide, $0.5-2.0 \%$ iron oxide, and small amounts of manganese dioxide, aluminum oxide, and sodium oxide. Whether in incense or in incense ash, most of the $\mathrm{Ca}, \mathrm{Mg}, \mathrm{Fe}$, and $\mathrm{Al}$ exist in the form of inorganic salts. Under high temperatures, waste wood materials produce little ash. When burning temperature rises from $538{ }^{\circ} \mathrm{C}$ to $1093{ }^{\circ} \mathrm{C}$, the quantity of wood ash drops by $45 \%$. At a temperature higher than $1000{ }^{\circ} \mathrm{C}$, carbonates and bicarbonates are broken up, resulting in 
reduced alkalinity in the ash and an increase in calcium oxide [8,9]. Moreover, raising the burning temperature can reduce the amount of metal elements such as $\mathrm{K}, \mathrm{Na}$, and $\mathrm{Zn}$ [10]. Udoeyo et al. [11] investigated the physical properties of wood ash and reported a specific weight of $2.43 \mathrm{~g} / \mathrm{cm}^{3}$, water content of $1.81 \%$, and $\mathrm{pH}$ of 10.48 . These properties make wood ash a suitable additive for cement. They also reported that when wood ash was used to replace $20-30 \%$ of cement, a slump of 0 resulted. Abdullahi [12] investigated the effect of wood ash on the slump of concrete and found that the amount of water required to maintain favorable workability increased as wood ash replaced cement [13]. Gupta et.al. [14] utilizes the biomass energy ash made from food and wood waste. The research results indicate that the biomass energy ash made from rice, meat, and vegetables has $71 \%$ carbon content instead of 1-2 $\mathrm{wt} \%$ in cement mortar, which can make mortar have better resistance to penetration. Using the ash of biomaterials as a substitute for cement can enhance the strength and durability of cement-based composite materials and reduce their permeability and cost, making it a major topic in research on building materials [15]. Researchers have started to explore the use of ash of biomaterials with different properties in cement-based composite materials. For ${ }^{`} t$ et al. [16] replaced the biomass ash of coal with the fly ash of burned wood, and test results for specimens cured for 28 days indicated that wood-based biomass ash could replace up to $30 \%$ of conventional Portland cement; the ash contained fewer hazardous elements and could be added into cement directly without processing. Kaminskas et al. [17] used biomass ash as a substitute for cement and tested its effect on compressive strength and found that it can substitute cement up to $15 \%$, the influence on the strength of which is mainly due to the hydration and the reaction of calcium silicate. Kuo et al. [18] replaced a portion of cement with rice husk ash and noted that doing so improved the durability and long-term strength of the concrete. In Sirico et al. [19], using wood waste as a resource for biomass gasification to turn it into biochar, the test results found that if appropriate biochar is added to the cement mortar, the compressive strength and flexural strength equivalent to the control group can be obtained, but it is broken. The capacity will be slightly increased. The application of wood biochar will not have a great negative impact on the mechanical properties of cement-based materials. It can also store the biochar in the building in the most stable manner, improving sustainable resource utilization. Lin et al. [20] replaced a portion of cement with the ash of joss paper and found that doing so resulted in greater long-term compressive strength of the concrete. Rajammaa et al. [21] observed through scanning electron microscopy (SEM) that replacing cement with the fly ash of biomaterials affected the durability of cement mortar. Researchers have also explored the use of industrial byproducts collected from channels such as coconut husk ash [22,23], hemp fiber [24,25], wood ash [26], and agave ash [27], which were ground or cut into a suitable size before being added into structural materials. Incense ash is $8-15 \%$ alkali metals, most of which is $\mathrm{K}(13 \%)$. The presence of alkali metals raises the $\mathrm{pH}$ of incense ash solution, making molecules require more kinetic energy to form embryo crystallites. Consequently, the presence of alkali metals increases the number of $\mathrm{Ca}(\mathrm{OH})_{2}$ and $\mathrm{C}-\mathrm{S}-\mathrm{H}$ unit cells in incense ash solution. Upon contact with water, innumerable micropores form on the surface of ash grains, facilitating the invasion of water molecules. At this moment, $\mathrm{Si}^{4+}$ ions detach from the surface and inside of ash grains and form silicate complexes, increasing the water retained in ash grains. Because the water-saturated incense ash contains large numbers of $\mathrm{Ca}$ and $\mathrm{Al}$ ions, when ash grains are wrapped by silicate, the high concentration of impurities in the grains increases the activation energy and degrees of freedom of these ions, enabling them to form unit cells that gradually expand and fill the micropores, thereby making the grains more compact and enhancing their compressive strength [28]. Most types of biomass ash can improve the long-term strength of concrete. Therefore, to make incense ash more effective and to achieve desirable early strength in concrete, curing temperatures must be investigated. Under a high curing temperature, the high activation energy increases the number of collisions between cement grains, hastening their hydrated reaction and in turn increasing the early strength of concrete [29]. The amount of $\mathrm{Ca}(\mathrm{OH})_{2}$ produced increases with the 
curing temperature, thus promoting a pozzolanic reaction by increasing cement's contact with $\mathrm{SiO}_{2}$ and $\mathrm{Al}_{2} \mathrm{O}_{3}$ in the ash [30]. Biomass ash has been used in structural concrete, but reports on the use of and relevant research on incense ash, which can be considered a special product of Taiwan, are scarce. If a method can be established to make use of incense ash, the effectiveness of incense ash can be ascertained. The material may become a resource that can be recycled for use in the concrete industry, with the dual benefits of waste reduction and environmental protection.

\section{Materials and Methods}

\subsection{Materials}

The incense ash used in this study was acquired from a temple in Kaohsiung, Taiwan. The ash went through a sieve analysis before being used as a substitute for cement. The material was identified as safe based on its toxicity characteristic leaching procedure (TCLP) leaching concentration and XRD. Table 1 presents the chemical analysis results and physical characteristics of the incense ash and cement. The incense ash was found to be similar to cement in chemical composition, with $\mathrm{SiO}_{2}, \mathrm{Al}_{2} \mathrm{O}_{3}$, and $\mathrm{CaO}$ being its major components. The natural sand used conformed to ASTM C33 [31]. Ordinary Type I Portland cement conforming to ASTM C150 [32] Type I Portland cement standards was used in the investigation.

Table 1. Chemical composition and physical properties of cement and incense ash.

\begin{tabular}{|c|c|c|c|}
\hline \multicolumn{2}{|c|}{ Chemical Composition (\%) } & Cement & Incense Ash \\
\hline \multicolumn{2}{|c|}{$\mathrm{SiO}_{2}$} & 21.31 & 12.95 \\
\hline \multicolumn{2}{|c|}{$\mathrm{Al}_{2} \mathrm{O}_{3}$} & 4.58 & 6.03 \\
\hline \multicolumn{2}{|c|}{$\mathrm{Fe}_{2} \mathrm{O}_{3}$} & 2.87 & 1.86 \\
\hline \multicolumn{2}{|c|}{$\mathrm{CaO}$} & 65.37 & 47.35 \\
\hline \multicolumn{2}{|c|}{$\mathrm{MgO}$} & 1.18 & 3.14 \\
\hline \multicolumn{2}{|c|}{$\mathrm{SO}_{3}$} & 2.13 & 3.62 \\
\hline \multicolumn{2}{|c|}{$\mathrm{K}_{2} \mathrm{O}$} & 0.62 & 5.09 \\
\hline \multicolumn{2}{|c|}{$\mathrm{Na}_{2} \mathrm{O}$} & 0.26 & 3.77 \\
\hline \multicolumn{2}{|c|}{ LOI } & - & 15.2 \\
\hline \multirow{2}{*}{ Physical property } & Fineness $\left(\mathrm{m}^{2} / \mathrm{kg}\right)$ & 321 & 688 \\
\hline & Specific gravity & 3.15 & 2.48 \\
\hline
\end{tabular}

\subsection{Mix Proportions}

The incense ash was used to replace $0-30 \%$ (volume) of cement in cement mortar, with water/binder ratios of 0.3 and 0.4 . The test specimens thus made were left to cure in water for up to 120 days at different temperatures $\left(25^{\circ} \mathrm{C}\right.$ and $\left.75^{\circ} \mathrm{C}\right)$. The researchers observed how the replacement ratio, curing temperature, and curing time affected the hydration behavior and engineering properties of the specimens.

\subsection{Methods}

The incense ash was mixed following the procedure specified in ASTM C305, specimens with incense ash replacing up to $30 \%$ (volume) of cement were produced, and two types, namely W/B 0.3 and 0.4 , were used. The newly-mixed mortar subsequently underwent tests to determine its fresh properties, including the water requirement for normal consistency and setting time (ASTM C187). After setting, the specimens, which were made in various replacement ratios, were cured under different temperatures $\left(25^{\circ} \mathrm{C}\right.$ and $\left.75^{\circ} \mathrm{C}\right)$ for $3,7,28,60$, and 120 days and then tested for compressive strength (ASTM C109) [33], heat conduction (ASTM E1225) [34], and water absorption (ASTM C642) [35] to determine their engineering properties. Afterward, a thermogravimetric analyzer (TGA) was used to explore their thermal behavior, and XRD and SEM were performed to determine the differences in microstructures and hydration products, respectively. 


\section{Results and Discussion}

\subsection{Effect of Incense Ash Replacement Ratio on Amount of Water Required for Normal Consistency and Setting Time of Cement Paste}

Table 2 presents the water requirement for normal consistency and setting time of cement paste specimens with different incense ash replacement ratios. The water requirement for normal consistency grew with the incense ash replacement ratio. Specifically, every $10 \%$ increase in incense ash replacement ratio caused the water requirement to rise by approximately $6 \%$. Therefore, incense ash can be surmised to require more water than cement. The appearance of an incense ash grain is a lump of irregular shape, with small particles forming cotton-like aggregates on the surface (Figure 1). Because the specific weight of incense ash is lower than that of cement, a greater volume of incense ash is required to replace the same weight of cement, increasing the water requirement. Both the initial and final setting time shortened as the replacement ratio increased, suggesting that incense ash becomes hydrated faster than cement. The results of physical property tests revealed that the incense ash had a fineness of $688 \mathrm{~m}^{2} / \mathrm{kg}$ and had a greater specific surface area than cement, making it bind with water more easily. Moreover, because incense ash has a smaller grain diameter and higher surface energy than cement, a rapid increase in surface area also causes the number of surface atoms to increase rapidly, thus hastening and intensifying the hydration reaction [36]. However, the incense ash only moderately affected setting time; even when $30 \%$ of cement was replaced by it, the setting time was shortened only by approximately $6 \mathrm{~min}$.

Table 2. Amount of water required for normal consistency and setting times of incense ash paste.

\begin{tabular}{cccc}
\hline $\begin{array}{c}\text { Incense Ash } \\
(\%)\end{array}$ & $\begin{array}{c}\text { Initial Setting Time } \\
\text { (min) }\end{array}$ & $\begin{array}{c}\text { Final Setting Time } \\
\text { (min) }\end{array}$ & $\begin{array}{c}\text { Amount of Water Required } \\
\text { for Normal Consistency (\%) }\end{array}$ \\
\hline 0 & 136 & 224 & 28.7 \\
10 & 135 & 223 & 30.5 \\
20 & 132 & 220 & 31.9 \\
30 & 128 & 218 & 33.9 \\
\hline
\end{tabular}

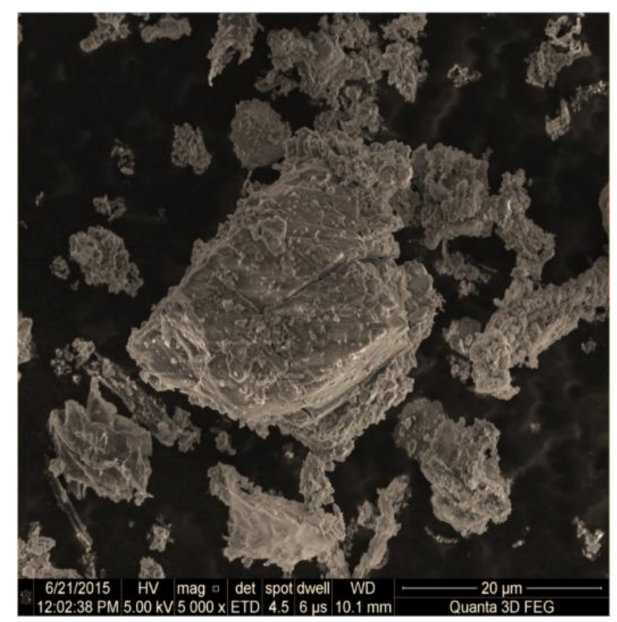

Figure 1. SEM analysis of incense ash $(\times 5000)$.

\subsection{Effect of Incense Ash on Mechanical Properties}

Figure 2 presents the compressive strength of specimens made with different water/binder ratios and replacement ratios and cured at $25^{\circ} \mathrm{C}$. Under two water/binder ratios, specimens with different replacement ratios exhibited a similar trend in their strength. Specifically, the strength by replacement ratio was $5 \%>$ control group $>10 \%>20 \%>30 \%$. Generally, when the replacement ratio was less than $5 \%$, the compressive strength of the specimens was comparable to that of the control group, regardless of their curing time, although some specimens did exhibit a greater compressive strength than did the control 
group. This differs from the finding of González-López [37]; replacing 5\% of cement with agave ash resulted in a greater compressive strength than the control group. At the $5 \%$ replacement ratio, incense ash serves as the filling material. However, at a ratio greater than $5 \%$, it obviously loses the filling function, which explains why no significant improvement in strength was observed in replacement ratios greater than $10 \%$. Furthermore, although strength did increase with curing time, it was still far inferior to that of the control group. This is because at a higher replacement ratio, the areas in cement mortar that are formerly filled by water form large voids that cannot be filled entirely by hydration products. The voids thus become defects that compromise compressive strength. Although the compressive strength at a $\mathrm{W} / \mathrm{C}=0.3$ was considerably greater than that achieved at a ratio of 0.4 , both had the same result - that $5 \%$ was the optimal replacement ratio. Therefore, $5 \%$ was established as the threshold for the replacement ratio. Figure 3 presents the compressive strength of specimens cured at $75^{\circ} \mathrm{C}$. The specimens cured at $75^{\circ} \mathrm{C}$ with a water/binder ratio of 0.4 achieved a compressive strength comparable to those cured at $25^{\circ} \mathrm{C}$ with a water/binder ratio of 0.3 . Such a result amply signifies that, at a high curing temperature, the greater activation energy facilitates the formation of $\mathrm{Ca}(\mathrm{OH})_{2}$; increases cement's contact with incense ash, $\mathrm{SiO}_{2}$, and $\mathrm{Al}_{2} \mathrm{O}_{3}$; and expedites the hydration reaction $[29,30]$. Thus, the strength of the specimens was enhanced.
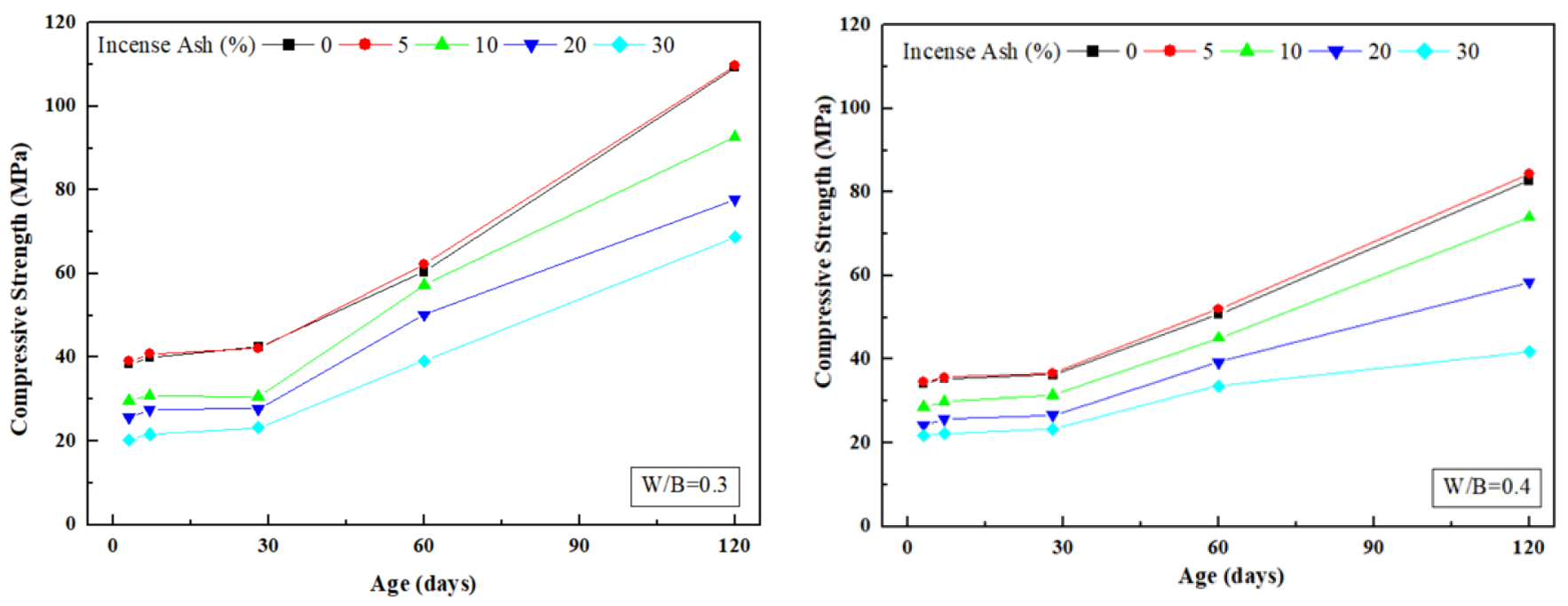

Figure 2. Compressive strength developments of incense ash paste $\left(25^{\circ} \mathrm{C}\right)$.
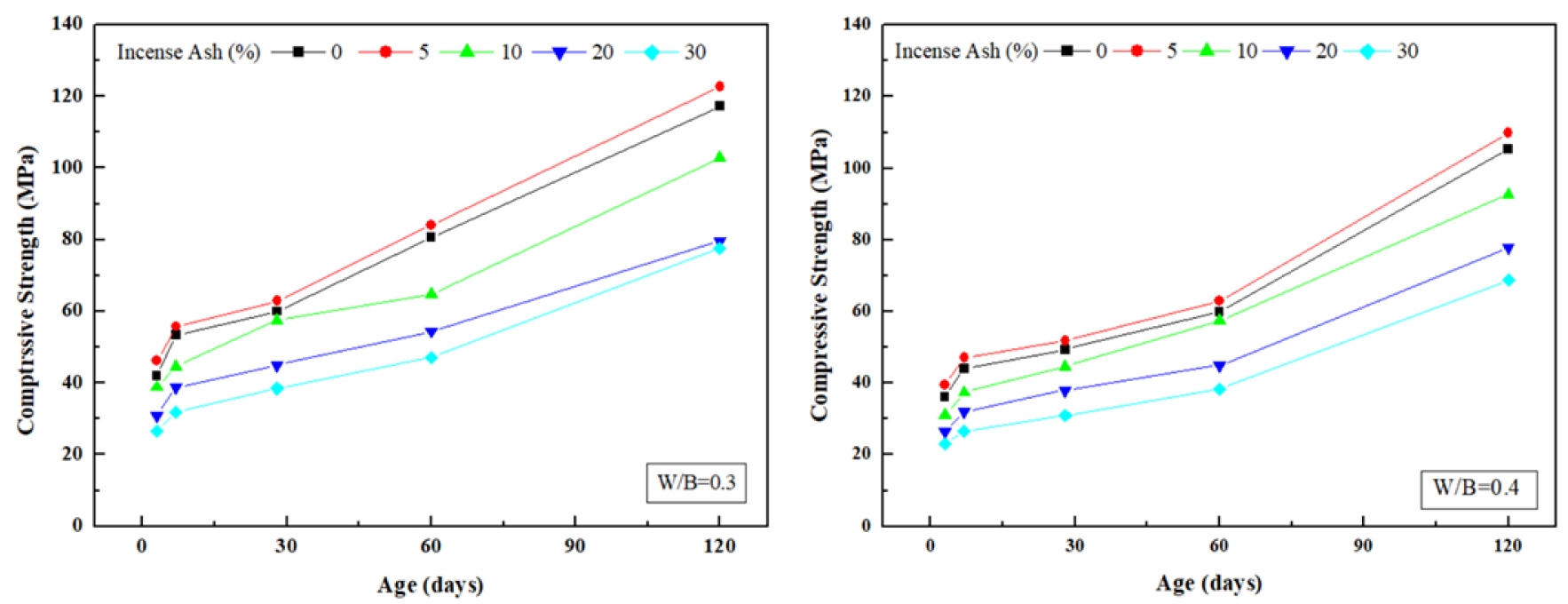

Figure 3. Compressive strength developments of incense ash paste $\left(75^{\circ} \mathrm{C}\right)$. 


\subsection{Thermogravimetric Analysis of Incense Ash Paste}

In the hydration process, cement forms various hydration products that, when heated at different temperatures, can break into different chemical compounds. Therefore, the researchers employed TGA to observe the weight loss of hydration products formed by cement mortar specimens that contained incense ash. Figure 4 presents the TGA results of specimens with different replacement ratios of incense ash. The weight of cement mortar mixed with pure water dropped as the temperature rose. In the hydration process, cement produces pore water, interlayer water, bound water, and crystallites. As a principle, pore water evaporates first as temperature rises, followed by interlayer water. When the temperature continues to rise, the bound water in compounds is broken up, followed by splitting decomposition of crystallites. At $110-160^{\circ} \mathrm{C}$, a significant weight loss occurred, which can be attributed to the dehydration caused by the loss of pore water. At $440-460{ }^{\circ} \mathrm{C}$, an endothermic peak was observed, which corresponded to the breaking up of $\mathrm{Ca}(\mathrm{OH})_{2}$. Another phenomenon that was observed at this stage was that as the replacement ratio of incense ash rose, the endothermic valley gradually leveled, representing the gradual diminishing of $\mathrm{Ca}(\mathrm{OH})_{2}$ content. At $500-650{ }^{\circ} \mathrm{C}$, splitting decomposition of $\mathrm{Ca}(\mathrm{OH})_{2}$ began, and a third endothermic peak was observed. After sintering at $800{ }^{\circ} \mathrm{C}$, weight loss amounted to $2.92 \%$, indicating that the weight loss was caused by the ignition loss of minerals during the sintering process.

\subsection{Heat Conduction of Incense Ash Paste}

Thermal conductivity is measured by dissipating and absorbing heat on a single probe to determine a unit area's temperature change over time; a low thermal conductivity coefficient corresponds to low thermal conductivity. As Figure 5 indicates, the thermal conductivity coefficient decreased as the incense ash replacement ratio increased. This occurred because incense ash has a lower specific weight than cement. As the replacement ratio increased, the voids in the cement grew in size and number, and the increased convective heat transfer and radiant heat transfer through the air in the voids caused the thermal conductivity coefficient to drop [38]. Incense ash is noncrystalline and contains various substances. In crystallites, because atoms have fixed positions, heat cannot be transferred directly through them but instead through waves created by the vibration of crystal lattices. Being noncrystalline, incense ash does not create waves through crystal lattices and is prone to phonon scattering. Because incense ash has a large specific surface area, it contains many closed pores that can impede heat wave transfer, which results in a low thermal conductivity coefficient. The thermal conductivity coefficients of the specimens increased with curing time. At an early stage when the pozzolanic reaction has yet to start, cement mortar with incense ash contains a considerable number of pores, causing its thermal conductivity coefficient to drop as pore water evaporates. With the passage of time, the progressive hydration produces $\mathrm{C}-\mathrm{S}-\mathrm{H}$ gel that gradually fills the pores, causing the thermal conductivity coefficient to steadily rise. However, when the water/binder ratio rises, the increased water content reduces the cement mortar's cementing ability. As a consequence, an excess of pores are formed and the cohesion of the cement mortar is compromised, which causes the thermal conductivity coefficient to drop. 


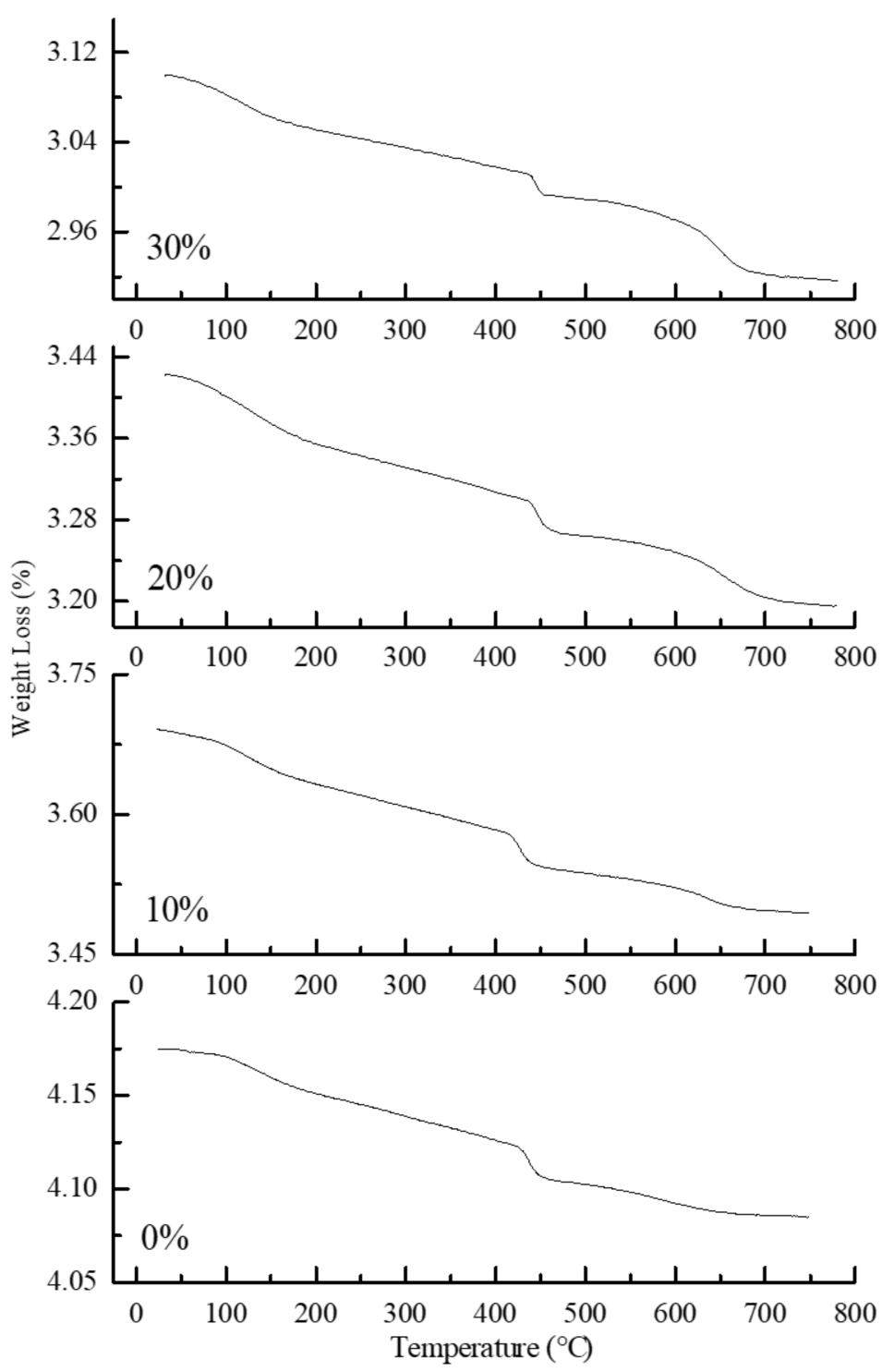

Figure 4. TGA of incense ash paste (replacement of cement $0-30 \% ; 120$ days).
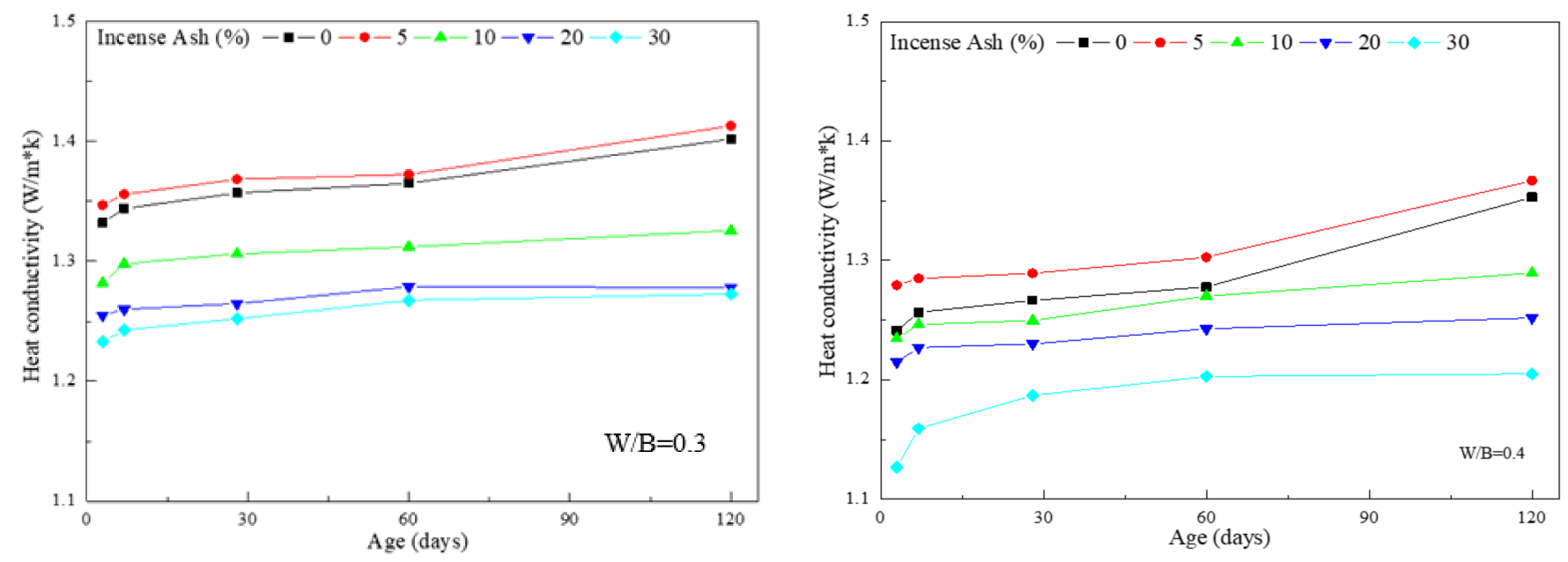

Figure 5. Thermal conductivity developments of incense ash paste. 


\subsection{Durability of Incense Ash Paste}

The number of pores is closely associated with the strength and durability of concrete. One method of assessing the durability of a specimen is estimating its water permeability based on its water absorption ratio. As Figure 6 indicates, at various incense ash replacement ratios, the water requirement decreased with the $\mathrm{W} / \mathrm{C}$. The number of pores is primarily determined by the amount of water used when mixing; therefore, the water absorption ratio increases with the water used. At a water/binder ratio $(\mathrm{W} / \mathrm{C})=0.3$, the water absorption test results of specimens cured for 3 days revealed that when the incense ash replacement ratio was $0 \%, 5 \%, 10 \%, 20 \%$, and $30 \%$, the water absorption ratio was $6.91 \%, 6.84 \%, 6.93 \%, 7.01 \%$, and $7.01 \%$, respectively. Because incense ash is finer than cement, more voids are created. Therefore, at a high replacement ratio, the increase in the number of pores results in a higher water absorption ratio. This is particularly evident at the $30 \%$ replacement ratio. Additionally, the water absorption ratio dropped as the curing time lengthened. This is because the pozzolanic reaction of $\mathrm{Ca}(\mathrm{OH})_{2}$ increased the cohesion of the cement mortar, and the hydration products also helped in filling the pores [39], causing the water absorption ratio to drop.

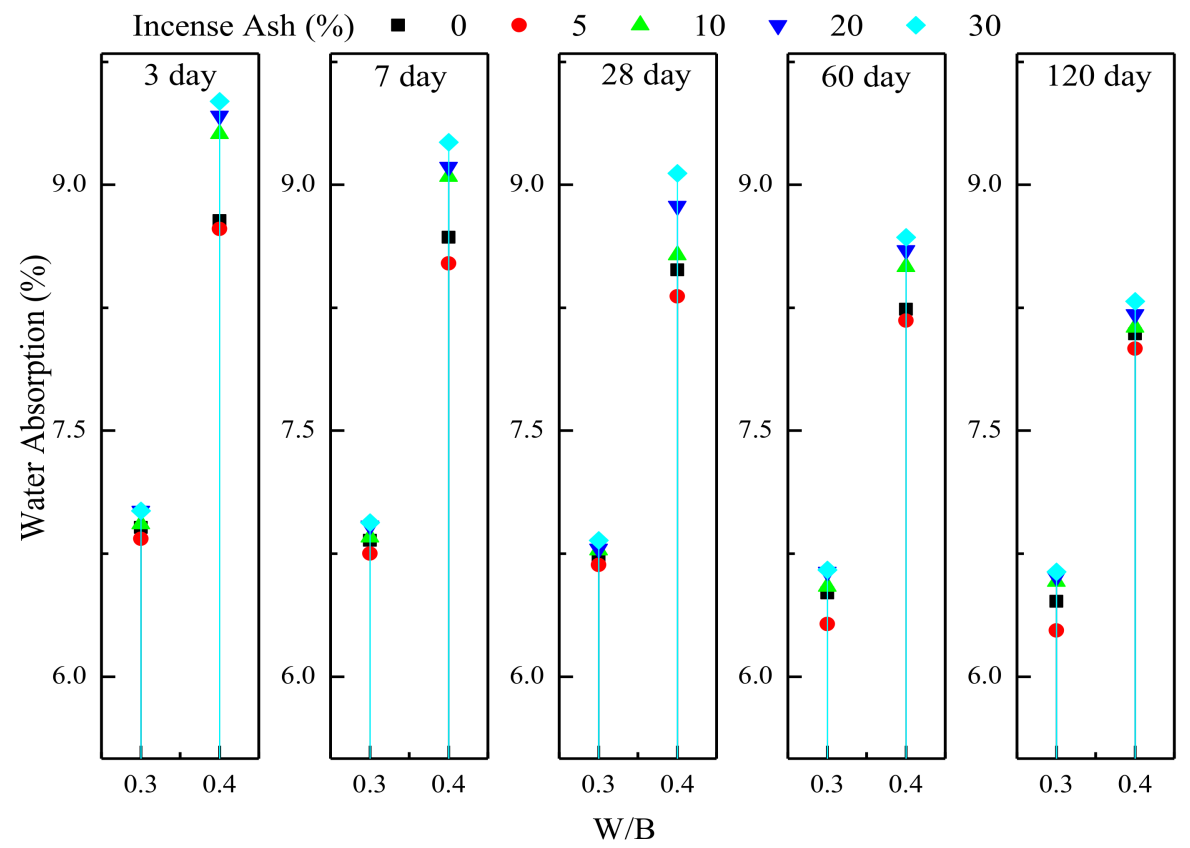

Figure 6. Absorptance rate of incense ash paste.

\subsection{XRD Analysis of Incense Ash Paste}

Figure 7 presents $\mathrm{XRD}$ analysis results of specimens of different replacement ratios with a $\mathrm{W} / \mathrm{C}=0.4$ and a curing time of 120 days. The peaks in the XRD patterns were observed to compare the development of hydration products. The results demonstrated that the peak of $\mathrm{Ca}(\mathrm{OH})_{2}$ diminished as the incense ash replacement ratio increased, as did the peak of $\mathrm{SiO}_{2}$, which disappeared in the XRD pattern by day 120. This suggests that the pozzolanic reaction that occurred in the late curing stage formed a $\mathrm{C}-\mathrm{S}-\mathrm{H}$ gel by binding $\mathrm{Ca}(\mathrm{OH})_{2}$ with an aluminum silicate group, which was reflected in the diminishing of $\mathrm{Ca}(\mathrm{OH})_{2}$ and $\mathrm{SiO}_{2}$ peaks as they were consumed. This also suggests that a higher replacement ratio requires a longer curing time, and cement mortar that hydrates well produces more hydration products. 


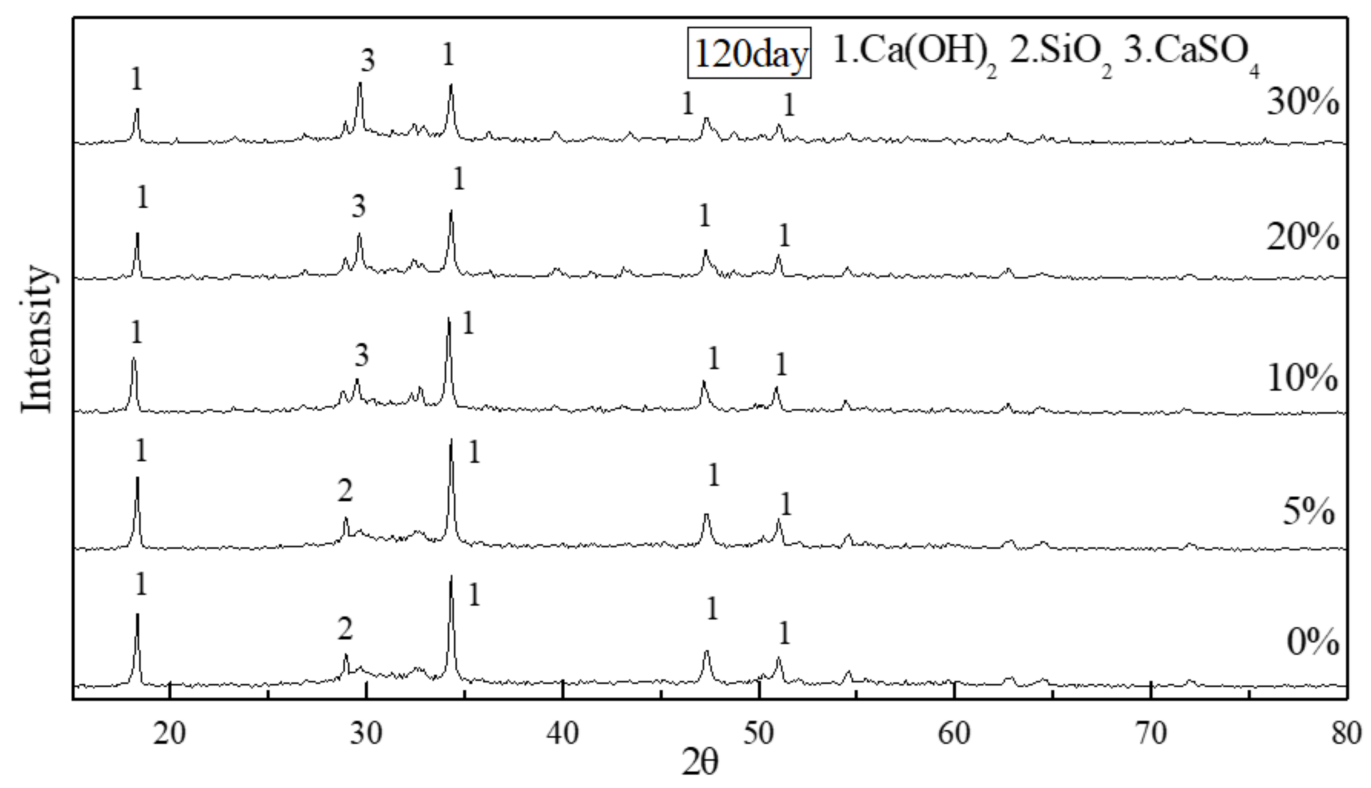

Figure 7. XRD diffraction patterns of incense ash pastes $(\mathrm{W} / \mathrm{B}=0.4 ; 120$ days).

\subsection{SEM Analysis of Incense Ash Paste}

Hydration was nearly complete in 120 days, by which time large amounts of C-S-H gel and other hydration products that were produced in the process had filled all the pores, increasing the cohesion of the structure. Therefore, hydration was verified to progress with curing, increasing the overall strength. In specimens with the $5 \%$ incense ash replacement ratio, the pores were filled with $\mathrm{C}-\mathrm{S}-\mathrm{H}$ gel, but not as much as in the control group. The congregation of C-S-H gel, which was affected by interparticle Van der Waals force and chemical bonds, made incense ash grains disappear completely. Incense ash grains formed C-S-H gel through a pozzolanic reaction, improving the crystalline morphology and cohesion of the specimens. At the replacement ratio of $30 \%$, large amounts of curly C-S-H gel and irregularly shaped monosulfoaluminate surrounded by minute pores were formed.

\section{Conclusions}

1. Incense ash has a high specific surface area and a high surface energy that expedites the hydration reaction, which caused the initial and final setting times to shorten.

2. When $5 \%$ of cement was replaced with incense ash, all the specimens had greater compressive strength than the control group. When more than $5 \%$ was replaced, the changes in compressive strength were nonsignificant, suggesting that $5 \%$ may be the optimal threshold value.

3. At a higher curing temperature, the activation energy provided by the heat can facilitate the formation of $\mathrm{Ca}(\mathrm{OH})_{2}$ and increase the number of collisions between material molecules, thus hastening the hydration reaction and improving the strength of specimens.

4. Thermal conductivity dropped as the replacement ratio grew. Increases in incense ash caused the voids in the cement to grow in size and number, and the increased convective heat transfer and radiant heat transfer through the air in the voids caused the thermal conductivity coefficient to drop.

5. Incense ash is finer than cement. Therefore, an increase in incense ash caused voids in the cement to increase in size and number, increasing water absorption.

6. The diminishing of $\mathrm{Ca}(\mathrm{OH})_{2}$ and $\mathrm{SiO}_{2}$ peaks in XRD results indicated their consumption; a higher replacement ratio required a longer curing time for hydration to be completed. 
Author Contributions: Conceptualization, W.-T.K. and T.-Y.C.; Data curation, C.-U.J. and T.-Y.C.; Formal analysis, W.-T.K. and C.-U.J.; Investigation, W.-T.K.; Methodology, W.-T.K. and T.-Y.C.; Project administration, W.-T.K.; Resources, W.-T.K. and T.-Y.C.; Supervision, W.-T.K.; Validation, W.-T.K. and C.-U.J.; Visualization, T.-Y.C.; Writing-review and editing, W.-T.K. and C.-U.J. All authors have read and agreed to the published version of the manuscript.

Funding: This research received no external funding.

Institutional Review Board Statement: Not applicable.

Informed Consent Statement: Not applicable.

Data Availability Statement: Not applicable.

Conflicts of Interest: The authors declare no conflict of interest.

\section{References}

1. Zhou, W. Distribution of Gaseous Pollutants and Metal Components of the Fly Ash and Burning Paper Money Worship Incense Arising. Master's Thesis, National Cheng Kung University, Tainan, Taiwan, 2007.

2. Ko, T.H.; Yang, C.R.; Huang, S.C.; Lin, C.Y. Effects of Charcoals addition to incense on air pollutant emissions. Combust. Q. 2012, 21, 43-55. [CrossRef]

3. Mario, B. Reuse of woody biomass fly ash in cement-based materials. Constr. Build. Mater. 2015, 76, $286-296$.

4. Carrasco-Hurtado, B.; Corpas-Iglesias, F.A.; Cruz-Pérez, N.; Terrados-Cepeda, J.; Pérez-Villarejo, L. Addition of bottom ash from biomass in calcium silicate masonry units for use as construction material with thermal insulating properties. Constr. Build. Mater. 2014, 52, 155-165. [CrossRef]

5. Vassilev, S.V.; Baxter, D.; Andersen, L.K.; Vassileva, C.G. An overview of the composition and application of biomass ash. Part 1. Phase-mineral and chemical composition and classification. Fuel 2013, 105, 40-76. [CrossRef]

6. Lin, T.C.; Yang, C.R.; Chang, F.H. Burning characteristics and emission products related to metallic content in incense. J. Hazard. Mater. 2007, 140, 165-172. [CrossRef]

7. Hawley, L.F.; Wise, L.E. The Chemistry of Wood; The Chemical Catalog Company Inc.: New York, NY, USA, 1926; pp. 119-120.

8. Chowdhury, S.; Mishra, M.; Suganya, O. The incorporation of wood waste ash as a partialcement replacement material for making structuralgrade concrete: An overview. Ain Shams Eng. J. 2015, 6, 429-437. [CrossRef]

9. Chee, B.C.; Mahyuddin, R. The implementation of wood waste ash as a partial replacement material in the production of structural grade concrete and mortar: An overview. Resour. Conserv. Recycl. 2011, 55, 69-85. [CrossRef]

10. Etiégni, L.; Campbell, A.G. Physical and chemical characteristics of wood ash. Bioresour. Technol. 1991, 37, 173-178. [CrossRef]

11. Udoeyo, F.F.; Inyang, H.; Young, D.T.; Oparadu, E.E. Potential of wood ash waste as an additive in concrete. J. Mater. Civ. Eng. 2006, 18, 605-611. [CrossRef]

12. Abdullahi, M. Characteristics of wood ash/OPC concrete. Leonardo Electron. J. Pract. Technol. 2006, 8, 9-16.

13. Gupta, S.; Kua, H.W.; Koh, H.J. Application of biochar from food and wood waste as green admixture for cement mortar. Sci. Total Environ. 2018, 619-620, 419-435. [CrossRef] [PubMed]

14. Vu, V.A.; Cloutier, A.; Bissonnette, B.; Blanchet, P.; Duchesne, J. The Effect of Wood Ash as a Partial Cement Replacement Material for Making Wood-Cement Panels. Materials 2019, 12, 2766. [CrossRef] [PubMed]

15. Tonoli, G.H.D.; Rodrigues Filho, U.P.; Savastano, H., Jr.; Bras, J.; Belgacem, M.N.; Rocco Lahr, F.A. Cellulose modified fibres in cement based composites. Compos. Part A 2009, 40, 2046-2053. [CrossRef]

16. Fořt, J.; Šál, J.; Ševčík, R.; Doleželová, M.; Keppert, M.; Jerman, M.; Záleská, M.; Stehel, V.; Černý, R. Biomass fly ash as an alternative to coal fly ash in blended cements: Functional aspects. Constr. Build. Mater. 2021, 271, 121544. [CrossRef]

17. Kaminskas, R.; Cesnauskas, V.; Kubiliute, R. Influence of different artificial additives on Portland cement hydration and hardening. Constr. Build. Mater. 2015, 95, 537-544. [CrossRef]

18. Kuo, W.T.; Her, Y.W.; Shu, C.Y. Properties and hydration of blended cements with rice husk ash. J. Technol. 2015, 30-40.

19. Sirico, A.; Bernardi, P.; Belletti, B.; Malcevschi, A.; Dalcanale, E.; Domenichelli, I.; Fornoni, P.; Moretti, E. Mechanical characterization of cement-based materials containing biochar from gasification. Constr. Build. Mater. 2020, 246, 118490. [CrossRef]

20. Lin, D.F. Effects on cement after partial replacement with burned joss paper ash. Environ. Technol. 2012, 22, 2595-2601. [CrossRef] [PubMed]

21. Rajamma, R. Biomass fly ash effect on fresh and hardened state properties of cement based materials. Compos. Part B 2015, 77, 1-9. [CrossRef]

22. Ramli, M.; Kwan, W.H.; Abas, N.F. Strength and durability of coconut-fiberreinforced concrete in aggressive environments. Constr. Build. Mater. 2013, 38, 554-566. [CrossRef]

23. Gunasekaran, K.; Annadurai, R.; Kumar, P.S. Study on reinforced lightweight coconut shell concrete beam behavior under flexure. Mater. Des. 2013, 46, 157-167. [CrossRef]

24. Merta, I.; Tschegg, E.K. Fracture energy of natural fibre reinforced concrete. Constr. Build. Mater. 2013, 40, 991-997. [CrossRef] 
25. Awwad, E.; Mabsout, M.; Hamad, B.; Farran, M.T.; Khatib, H. Studies on fiber-reinforced concrete using industrial hemp fibers. Constr. Build. Mater. 2012, 35, 710-717. [CrossRef]

26. Bederina, M.; Gotteicha, M.; Belhadj, B.; Dheily, R.M.; Khenfer, M.M.; Queneudec, M. Drying shrinkage studies of wood sand concrete-effect of different wood treatments. Constr. Build. Mater. 2012, 36, 1066-1075. [CrossRef]

27. Juárez, C.; Guevara, B.; Valdez, P.; Durán-Herrera, A. Mechanical properties of natural fibers reinforced sustainable masonry. Constr. Build. Mater. 2010, 24, 1536-1541. [CrossRef]

28. Koohestani, B.; Koubaa, A.; Belem, T.; Bussière BBouzahzah, H. Experimental investigation of mechanical and microstructural properties of cemented paste backfill containing maple-wood filler. Constr. Build. Mater. 2016, 121, 222-228. [CrossRef]

29. Zhang, Z.; Wang, Q.; Chen, H. Properties of high-limestone powder concrete under standard curing and steam-curing conditions. Powder Technol. 2016, 301, 16-25. [CrossRef]

30. Thongsanitgarn, P.; Wongkeo, W.; Chaipanich, A.; Poon, C.S. Heat of hydration of Portland high-calcium fly ash cement incorporating limestone powder: Effect of limestone particle size. Constr. Build. Mater. 2014, 66, 410-417. [CrossRef]

31. ASTM C33. Standard Specification for Concrete Aggregates; ASTM International: West Conshohocken, PA, USA, 2013.

32. ASTM C150. Standard Specification for Portland Cement; ASTM International: West Conshohocken, PA, USA, 2020.

33. ASTM C109/C109M-16a. Standard Test Method for Compressive Strength of Hydraulic Cement Mortars (Using 2-in. or [50-mm] Cube Specimens); ASTM International: West Conshohocken, PA, USA, 2016.

34. ASTM E1225. Standard Test Method for Thermal Conductivity of Solids Using the Guarded-Comparative-Longitudinal Heat Flow Technique; ASTM International: West Conshohocken, PA, USA, 2013.

35. ASTM C642. Standard Test Method for Density, Absorption, and Voids in Hardened Concrete; ASTM International: West Conshohocken, PA, USA, 2013.

36. Kuo, W.-T. Effect of nano-SiO ${ }_{2}$ on the fresh behaviors of water works sludge ash paste speclmens. J. Technol. 2008, 23, 155-160.

37. González-López, J.R.; Ramos-Lara, J.F.; Zaldivar-Cadena, A. Small addition effect of agave biomass ashes in cement mortars. Fuel Process. Technol. 2015, 133, 35-42. [CrossRef]

38. Carrasco, B.; Cruz, N.; Terrados, J.; Corpas, F.A.; Pérez, L. An evaluation of bottom ash from plant biomass as a replacement for cement in building blocks. Fuel 2014, 118, 272-280. [CrossRef]

39. Hossain, M.M.; Karim, M.R.; Hasan, M.; Hossain, M.K.; Zain, M.F.M. Durability of mortar and concrete made up of pozzolans as a partial replacement of cement: A review. Constr. Build. Mater. 2016, 116, 128-140. [CrossRef] 